\title{
НОГООН БУСИЙН ШИНЭСЭН (Larix sibirica Ldb.) ОЙН ҮРЛЭЛТ ҮРИЙН ЧАНАРТ АГААРЫН БОХИРДЛЫН ҮЗУУЛЭХ НӨЛӨӨ
}

\author{
Б. Удвал ${ }^{1}$, Ц.Дашзэвэг
}

${ }^{1}$ Газарзүй-Геоэкологийн хүрээлэн, Шинжлэх ухааны академи, Монгол улс Цахим шуудан: bayarsaikhanudval@gmail.com

\section{ОРШИЛ}

Улаанбаатар хотын ногоон бүсийн ой нь хотын усан хангамжийн эх үүсвэр Туул гол, түүнд цутгадаг гол горхины эх авдаг хот орчмын уулсын ой модны ус зохицуулах, хөрс хамгаалах, уур амьсгалыг зөөлрүүлэх, хүлэмжийн хий болон агаарын бохирдлыг бууруулах, нийслэл хотын эмх замбараагүй тэлэлтийг хязгаарлах, хэт төвлөрлийг сааруулах, байгалийн тэнцвэрт байдлыг хадгалах, оршин суугчдын эрүүл, ая тухтай орчинд амьдрах нөхцөл бололцоог бүрдүүлж байдаг.

Улаанбаатар хот нь далайн түвшнээс дээш 1350 метр өндөрт, дөрвөн уулаар хүрээлүүлэн оршдог бөгөөд салхины дундаж хурд 1-2 м/секунд буюу агаарын урсгал харьцангуй тогтуун байдаг онцлогтой. Нийслэл хотын салхины зонхилох чиглэлийн дагуу байрлах дулааны цахилгаан станц, дөрвөн уулын бэл орчмоос эхлэн хотын төв хүртэл тархсан гэр хорооллын айлуудын галлагааны утаа, тээврийн хэрэгслийн ялгаруулж буй бохирдол нь хотын төв хэсэгт хөдөлгөөнгүй тогтож, агаарын бохирдлыг бий болгож байна. Нийслэлийн агаарын бохирдлын гол үзүүлэлт нь хүхэрлэг хий, азотын давхар исэл, нүүрстөрөгчийн дутуу исэл, нүүрсхүчлийн хий, элдэв төрлийн бодис агуулсан тоос, тортог бөгөөд жилээс жилд эдгээр бохирдуулагчийн хэмжээ нэмэгдэж агаарын чанар доройтож, улмаар ногоон байгууламж, ногоон бүсийн ойд сөрөг нөлөө үзүүлсээр байна.

Судалгааны дүнгээс үзэхэд агаар бохирдуулагч хүнд элементүүд нь модлог ургамлын навч, шилмүүсний анатомын бүтэц, эпидермисийн давхраа, эд эсийн бүтцэд сөргөөр нөлөөлөн модлог ургамлын анатомын бүтцийг өөрчилж, хэвийн бус болгодог ба ургамлын эпидермийн эс, кутикулийн давхрааг өөрчилж амьсгалын аппаратын тоог ихэсгэх буюу багасгадаг байна [13]. Мод нь хөрснөөс үндсээрээ дамжуулан, хур тунадас болон агаараас навч, шилмүүсээр дамжуулан хүнд элементүүдээр бохирддог бөгөөд агаар дахь хүнд металлын ургамалд үзүүлэх нөлөөг судалсан олон арван судалгааны үр дүн байдаг.

Шилмүүст моддын хувьд цэцэглэж, тоос хүртэхээс эхлээд үр боловсрох хүртэл удаан хугацаанд үргэлжилдэг тул хүний үйл ажиллагаанаас үүссэн бохирдолд 
илүҮ мэдрэмтгий байдаг [12]. Ялангуяа үр боловсрох хугацаа удаан явагддаг (24-36 сар) нарсны овгийн хувьд ургамлын ДНХ-д сөрөг нөлөө үзүүлдэг болохыг судалсан байна. Үрт ургамлын үржлийн эрхтэн нь авто машинаас үүссэн агаар бохирдуулагч хүнд элементүүдэд илүү мэдрэмтгий байдаг бөгөөд ачаалал ихтэй авто замын ойролцоо ургаж буй ургамлын үрлэлт нь буурч, хэвийн бус хөврөлийн тоо хоёр дахин ихссэн болохыг илрүүлсэн байна [11].

Улаанбаатар хотын ногоон бүсийн ойн сангийн нийт талбай 227263 га бөгөөд Үүний 212442 га буюу 93.48\%-ийг ойн талбай, 14821га буюу 6.52\%-ийг ойн бус талбай эзэлж байна. Ойн талбайн 171935 га буюу 81\% нь ойгоор бүрхэгдсэн 40507 га буюу $19 \%$ нь ойгоор бүрхэгдээгүй талбай эзлэх бөгөөд ойрхог чанар $32.4 \%$ байна. Ойгоор бүрхэгдсэн талбайн 153057 га-г байгалийн ой, 18863 га-г бут сөөг, 15 га-г таримал ой эзэлдэг. Ойгоор бүрхэгдээгүй талбайн 12076 га нь түймэрт, 5396 га нь ойн хөнөөлт шавж, өвчинд нэрвэгдсэн ой, 13494 га нь тармаг мод, 1833 га талбайд ой тэлж ургаж байна. 1314 га нь зориудаар ойжуулсан, 6394 га нь мод бэлтгэсэн талбай байна. Ойгоор бүрхэгдсэн талбайн $85.5 \%$-ийг байгалийн ой эзлэх бөгөөд бүрэлдэхүүний хувьд шинэс, хуш, нарс, хус зонхилох бөгөөд улиангар, гацуур, улиас, бургас харьцангуйгаар бага талбайд тархан ургана [7].

ТҮлхүҮр үг: үрийн ургаи, соёололт, ургах эрчим, 1000 үрийн жин, үр, боргоцой, үрийн далавч

\section{МАТЕРИАЛ, АРГА ЗУЙ}

Судалгааны дээж талбайг тусгаарлах, моддын таксацын үндсэн үзүүлэлтийг тодорхойлоход Н.П.Анучины [1] арга зүйгээр, үрлэлтийн байдлыг А.А. Корчагины [5] аргаaр үнэлэв. Үрийн чанарын үзүүлэлтүүдийг тодорхойлохдоо олон улсын үр шинжилгээний журам [15], Монгол улсын мод, сөөгний үрийг шинжлэх стандарт (MNS 2430:2009;
MNS 2432:2009; MNS 2887:2009; MNS 5994:2009)-ыг үндэслэл болгосон [8]. Өгөгдөл боловсруулалтыг JMP 5.1, SPSS 17 зэрэг статистикийн багц программуудыг ашиглан гүйцэтгэсэн.

Судалгаанд агаарын бохирдлын төв цэг болох Улаанбаатар хотоос алслагдах зайгаар нь хойд болон урд чиглэлд 10,15 , 20, 30 км-т дээж талбайг байгуулсан болно. 


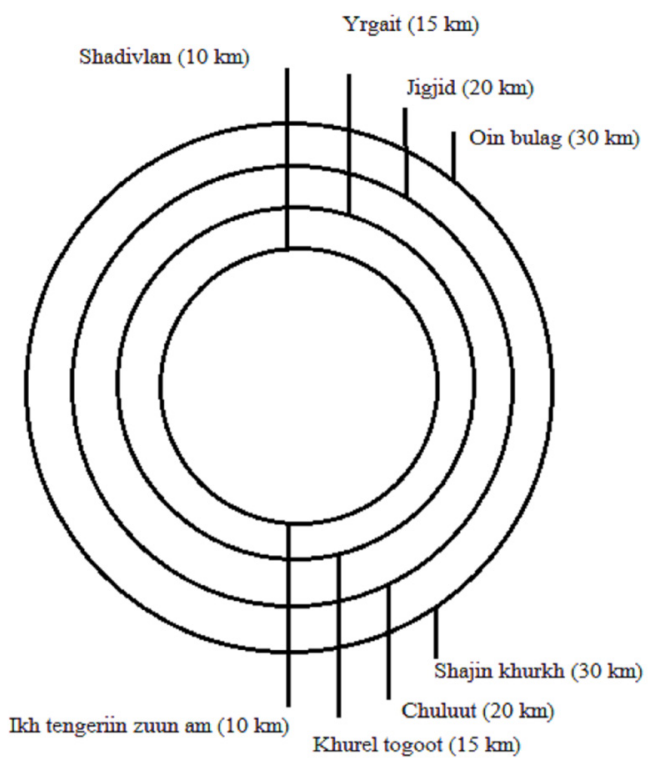

Зураг 1. Судалгааны талбайн бариил

\section{ҮР ДҮН, ХЭЛЦЭМЖ}

Ногоон бүсийн шинэсэн ойд судалгааны дээж талбай тус бүрийн таксацын үндсэн

үзүүлэлтүүдийг тодорхойлж хүснэгт 1-ээр үзүүлэв.

Хүснэгт 1. Дээж талбайн үндсэн ҮзуҮлэлт

\begin{tabular}{|c|c|c|c|c|c|c|c|}
\hline $\begin{array}{c}\text { Дээж } \\
\text { талбай }\end{array}$ & $\begin{array}{c}\text { Бүрэл } \\
\text { дэхүүн }\end{array}$ & Өтгөрөл & $\begin{array}{c}\text { Насны } \\
\text { анги/нас }\end{array}$ & $\begin{array}{c}\text { Дундаж } \\
\text { диаметр, } \\
\text { см }\end{array}$ & $\begin{array}{c}\text { Дундаж } \\
\text { өндөр, } \\
\text { м }\end{array}$ & Бонитет & $\begin{array}{c}\text { Нөөц, } \\
\text { м³/га }\end{array}$ \\
\hline Ш & 10Ш & 0.8 & $\mathrm{YI} / 110$ & 21.4 & 16.7 & IY & 215 \\
\hline Ят & $9 ш 1 X c+X ш$ & 0.8 & $\mathrm{IY} / 80$ & 15.0 & 13.9 & $Y$ & 213 \\
\hline ж & $10 Ш+X c$ & 0.8 & $\mathrm{Y} / 90$ & 20.3 & 19.0 & III & 276 \\
\hline OБ & 10ш Хш H & 0.8 & $\mathrm{YI} / 120$ & 21.9 & 20.5 & IY & 254 \\
\hline 3т & 10Ш & 0.7 & $\mathrm{IY} / 80$ & 16.9 & 14.9 & IY & 160 \\
\hline $\mathrm{XT}$ & 10ш & 0.9 & $\mathrm{YI} / 120$ & 25.4 & 20.0 & IY & 382 \\
\hline Чт & 10Ш & 0.7 & $\mathrm{YI} / 110$ & 17.1 & 15.0 & $Y$ & 164 \\
\hline ШX & 10Ш & 0.6 & $\mathrm{Y} / 100$ & 28.9 & 22.6 & III & 207 \\
\hline
\end{tabular}

ХT - Хүрэл тогоот, Ч - Чулуут, ШХ-Шажин хурах.

Ой орон зайнхаа боломжийг хэдий чинээ бүрэн ашиглавал модны нөөц, өгөөж нь төдий чинээ их байх бөгөөд энэХүҮ орон зайн ашиглалтын түвшинг өтгөрөл гэсэн үзүүлэлтээр илэрхийлэх ба хамгийн бага үзүүлэлттэй нь Шажин хурхын аманд сонгосон дээж талбайд 0.6 , бусад дээж талбайд 0.7-0.9 байна. Ой нь модны төрөл, насаар ижил боловч хөрс, уур амьсгал, ой ургамалжилтын мужлал зэрэг ургах орчны 
онцлогоос шалтгаалан ойн өсөлтийн явц харилцан адилгүй байдаг. Ойн бонитетийн ангиллыг тодорхой насны моддын дундаж өндөр хэдий чинээ их байвал тухайн ойн ургах орчны нөхцөл тэр хэмжээгээрээ сайн байна гэсэн зарчимд тулгуурлан тогтоодог бөгөөд талбайнуудын хувьд ойн ургах орчны нөхцөлийн III-IY ангид хамаарагдаж байна.

\section{Моддын өсөлтийн үнэлгээ}

Ойн бүлгэмдэлд үзүүлж буй байгалийн болон хүний хүчин зүйлийн нөлөөг судлахад төрөл бүрийн ангилал, үзүүлэлт, шалгууруудыг ашигладаг. Судалгааны талбайн моддод Крафтын өсөлтийн ангиллаар [2] үнэлгээ өгч, ангилал тус бүрт моддын эзлэх хувийг дараах хүснэгтээр үзүүлэв.

ХУснэгт 2. Моддын Крафтын ангиллаар тархах ҮзУҮлэлт

\begin{tabular}{|c|c|c|c|c|c|c|}
\hline \multirow{2}{*}{$\begin{array}{c}\text { Дээж } \\
\text { талбай }\end{array}$} & $\begin{array}{c}\text { Хотоос } \\
\text { алслагдах зай }\end{array}$ & $\mathrm{I}$ & $\mathrm{II}$ & $\mathrm{III}$ & $\mathrm{IY}$ & Крафтын ангилал,\% \\
\hline \multicolumn{7}{|c|}{ Хотын хойд зүгт байрлах цэгүүд } \\
\hline Ш & 10 км & 4.8 & 42.7 & 10.4 & 22.6 & 19.5 \\
\hline Я & 15 км & 13.1 & 27.1 & 11.2 & 44.9 & 3.7 \\
\hline Ж & 20 км & 12.0 & 32.0 & 10.7 & 44.0 & 1.3 \\
\hline ОБ & 30 км & 13.0 & 19.5 & 34.1 & 18.7 & 14.8 \\
\hline \multicolumn{7}{|c|}{ Хотын урд зүгт байрлах цэгүүд } \\
\hline 3 & 10 км & 6.6 & 31.4 & 5.9 & 35.5 & 20.6 \\
\hline ХТ & 15 км & 4.5 & 24.9 & 5.5 & 40.3 & 24.8 \\
\hline 4 & 20 км & 3.3 & 51.1 & 17.4 & 21.7 & 6.5 \\
\hline ШХ & 30 км & 10.8 & 40.5 & 8.1 & 21.7 & 18.9 \\
\hline
\end{tabular}

Улаанбаатар хотоос хойд зүгт сонгосон талбайн моддын өсөлтийн ангиар тархах үзүүлэлтээс харахад 10 км зайд сонгосон талбайд I-III ангид 57.9\%, өсөлтөөр хоцорсон, хатсан моддын IY-Y ангилалд $42.1 \%$ хамрагдаж байгаа бөгөөд 15 км зайд сонгосон талбайд I-III ангилалд 51.4\%, IY-Y ангид 48.6\%, 20 км зайд сонгосон талбайд
$54.7 \%$ нь I-III ангилалд, 45.3\% нь IY-Y ангид, 30 км зайд сонгосон талбайд 66.5\% нь I-III ангид, 33.5\% нь IY-Y ангид тус тус хамаарагдаж байна. Эндээс үзэхэд агаарын бохирдол ихтэй төв цэгээс алслагдах тусам өсөлтөөр хоцорсон, хатсан моддын эзлэх хувь бага, үр өгөх чадвар болон өсөлт сайтай моддын эзлэх хувь илүү байна.

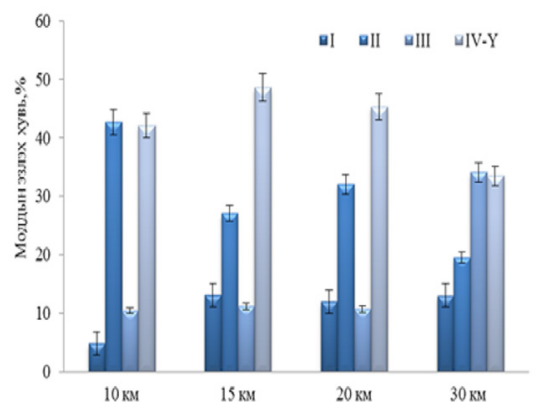

Зураг 2. Хойд зугт сонгосон талбайн моддын өсөлтийн ангиар тархах ҮзүҮлэлт

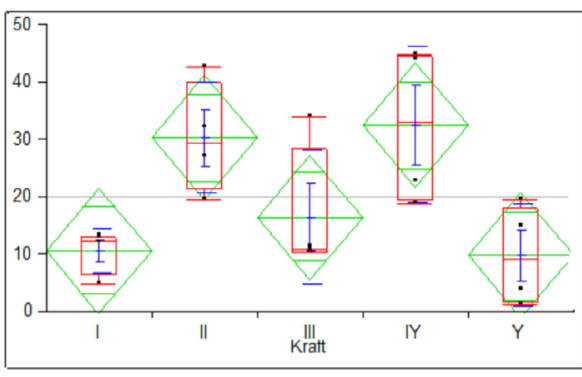

Зураг 3. Крафтын ангилалд моддын тархах YзҮҮлэлтийн ялгаа $F=4.5234 d f=4 p=0.0135$ 


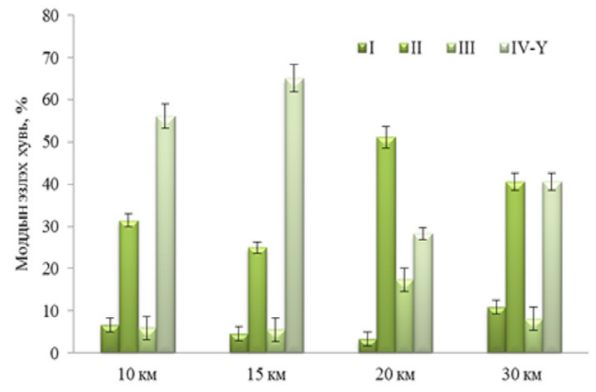

Зураг 4. Өмнө зугт сонгосон талбайн моддын өсөлтийн ангиар тархах үзүүлэлт

Улаанбаатар хотоос өмнө зүгт сонгосон дээж талбайн моддын өсөлтийн ангиар тархах үзүүлэлтээс харахад 10 км зайд сонгосон талбайд I-III ангид 43.9\%, өсөлтөөр хоцорсон, хатсан моддын IY-Y ангилалд 56.1\% байгаа бөгөөд 15 км зайд сонгосон талбайд I-III ангилалд $34.9 \%$, IY-Y ангид $65.1 \%, 20$ км зайд сонгосон талбайд $71.8 \%$ нь I-III ангилалд, 28.2\% нь IY-Y ангид, 30 км зайд сонгосон талбайд 59.4\% нь I-III ангид, 40.6\% нь IY-Y ангид тархаж, агаарын бохирдол ихтэй төв цэгтэй ойр талбайнуудад өсөлтөөр хоцорсон, хатсан ангиллын моддын эзлэх хувь зонхилж байна. Судалгааны дүнгээс үзэхэд Улаанбаатар хотын ногоон бүсийн ой агаарын бохирдол болон рекреаци ашиглалтын нөлөөнд ихээхэн өртөж моддын бүтцийн зүй тогтол алдагдсан болохыг харуулж байна.

Улаанбаатар хотоос хойд зүгт

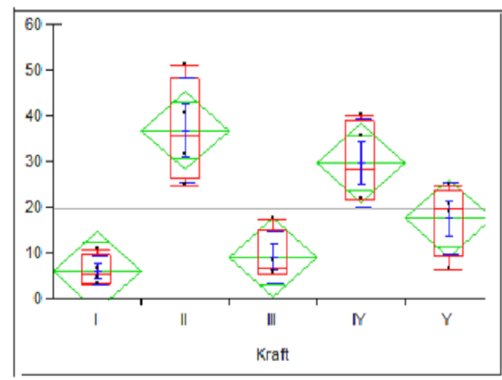

Зураг 5. Крафтын ангилалд моддын тархах УзҮҮлэлтийн ялгаа $F=10.6756 \mathrm{df}=4 p=0.0003$

сонгосон талбайнууд засаг захиргааны хувиарлалтаар Сүхбаатар болон Чингэлтэй дүүрэгт, урд зүгт сонгосон талбайнууд ХанУул, Баянзүрх дүүрэгт хамаарагдаж байна. Нийслэлийн агаарын чанарын албаны 2013 оны тайлангаас дүүргүүдийн нутаг дэвсгэрт хийсэн агаарт агуулагдах бохирдуулагч бодисуудын дундаж агууламжийн хэмжээг тодорхойлсон дүнгээс харахад (хүснэгт 3) Сүхбаатар болон Чингэлтэй дүүргийн нутаг дэвсгэрт агаарт агуулагдах хүхрийн давхар исэл, азотын давхар исэл, нүүрстөрөгчийн дутуу исэл, 10 мкм болон 2.5 мкм-ээс бага хэмжээтэй тоосонцорын массын дундаж агууламжийн нийлбэр үзүүлэлт нь хамгийн их буюу өөрөөр хэлбэл хамгийн их бохирдолтой байна. Харин Баянзүрх, Хан-Уул дүүрэгт бохирдол харьцангуй бага үзүүлэлттэй байна

Хүснэгт 3. Агаарт агуулагдах бохирдуулагч бодисуудын дундаж агууламжийн хэмжээ

\begin{tabular}{|c|c|c|}
\hline № & Дүүрэг & $\begin{array}{c}1 \mathrm{M}^{3} \text { агаарт агуулагдах бохирдуулагч бодисуудын } \\
\text { массын дундаж агуламжийн нийлбэр, мг/м3 } \\
\left(\mathrm{CO}+\mathrm{NO}^{2}+\mathrm{SO}_{2}+\mathrm{PM} 2.5+\mathrm{PM} 10\right)\end{array}$ \\
\hline 1 & Сүхбаатар & 11.7 \\
\hline 2 & Чингэлтэй & 10.42 \\
\hline 3 & Сонгинохайрхан & 10.3 \\
\hline 4 & Баянгол & 6.83 \\
\hline 5 & Баянзүрх & 5.55 \\
\hline 6 & Хан-Уул & 2.96 \\
\hline
\end{tabular}


Моддын өсөлтийн ангиллын үнэлгээг дээрх хүснэгтийн үр дүнтэй харьцуулж үзэхэд ойн моддын өсөлтөнд агаарын бохирдлын эх үүсвэрүүд тодорхой хэмжээгээр нөлөө үзүүлсэн болохыг харуулж байна.

\section{Селекцийн үнэлгээ}

Селекцийн ангилал нь генетикийн шинжлэх ухааны ололтод үндэслэн, аж ахуйн ашигтай талыг харгалзан моддыг үнэлдэг арга [3, 4, 6, 9] бөгөөд судалгааны талбай тус бүрт үнэлгээ өгч моддын тархах тоон үзүүлэлтийг хувиар илэрхийлэн хүснэгт 4-т үзүүлэв.

ХУснэгт 4. Селекцийн ангиллаар моддын тархах үзуүлэлт

\begin{tabular}{|c|c|c|c|c|c|}
\hline \multirow{2}{*}{$\begin{array}{c}\text { Дээж } \\
\text { талбай }\end{array}$} & $\begin{array}{c}\text { Хотоос } \\
\text { алслагдах зай }\end{array}$ & \multicolumn{2}{|c|}{ Селекцийн үнэлгээний эзлэх хувь } & \multirow{2}{*}{ Селекцийн үнэлгээ } \\
\cline { 3 - 5 } & Шилмэл & Хэвийн & \multirow{2}{*}{ Доогуур чанарын } & \\
\hline \multicolumn{7}{|c|}{ Хотын хойд зүгт байрлах цэгүүд } \\
\hline Ш & 10 км & 4.8 & 53.2 & 41.9 & Хэвийн \\
\hline Я & 15 км & 13.1 & 38.3 & 48.6 & Доогуур чанарын \\
\hline Ж & 20 км & 12.0 & 42.7 & 45.3 & Доогуур чанарын \\
\hline ОБ & 30 км & 13.0 & 47.2 & 39.5 & Хэвийн \\
\hline \multicolumn{7}{|c|}{ Хотын урд зүгт байрлах цэгүҮд } & Доогуур чанарын \\
\hline 3 & 10 км & 6.6 & 37.1 & 56.1 & Доогуур чанарын \\
\hline ХТ & 15 км & 4.5 & 31.8 & 63.7 & Хэвийн \\
\hline Ч & 20 км & 3.3 & 69.5 & 27.2 & Хэвийн \\
\hline ШХ & 30 км & 10.8 & 45.9 & 43.2 & \\
\hline
\end{tabular}

Судалгааны талбай тус бүрт селекцийн ангиллаар үнэлгээ өгөхөд, Улаанбаатар хотоос хойд зүгт 10 км-т Шадивланд тусгаарласан талбайд шилмэл модод дунджаар 4.8 хувь, хэвийн модод 53.2 хувь, доогуур чанарын модод 41.9 хувь буюу хэвийн модод зонхилж, 15 км-т Яргайтад сонгосон талбайн моддын 13.1 хувь нь шилмэл, 38.3 хувь нь хэвийн, 48.6 хувь нь доогуур чанарын модод буюу энэ талбайд доогуур чанарын модод зонхилон тархаж, 20 км-т Жигжидийн аманд сонгосон ойд 12 хувь нь шилмэл, 42.7 хувь нь хэвийн, 45.3 хувийг доогуур чанарын модод эзэлж нийт моддын зонхилох хувийг доогуур чанарын модод эзэлж, 30 км-т Ойн булагт сонгосон дээж талбайд шилмэл модод дунджаар 13 хувь, хэвийн модод 47.2 хувь, доогуур чанарын модод 39.5 хувь буюу хэвийн модод зонхилж байна.

Улаанбаатар хотоос урд зүгт 10 км зайд сонгосон Залаатын амны ойн моддын 6.6 хувийг шилмэл, 37.1 хувийг хэвийн,
56.1 хувийг доогуур чанарын модод эзэлж энэ талбайд селекцийн ангиллаар доогуур чанарын модод зонхилж, 15 км-т Хүрэлтогоотын амны ойд 4.5 хувийг шилмэл, 31.8 хувийг хэвийн, 63.7 хувийг доогуур чанарын модод эзэлж, энэ талбайд селекцийн ангиллаар доогуур чанарын модод зонхилж, 20 км-т сонгосон Чулуутын амны ойд 3.3 хувийг шилмэл, 69.5 хувийг хэвийн, 27.2 хувийг доогуур чанарын модод эзэлж энэ талбайд селекцийн ангиллаар хэвийн модод зонхилж, 30 км -т Шажин хурхын аманд сонгосон талбайд 10.8 хувийг шилмэл, 45.9 хувийг хэвийн, 43.2 хувийг доогуур чанарын модод эзэлж хэвийн модод зонхилж байна.

Эндээс үзэхэд агаарын бохирдлын эх үүсвэр, төв цэгээс алслагдах тусам хэвийн моддын эзлэх хувь нэмэгдэж, доогуур чанарын ангиллын моддын эзлэх хувь бага, агаарын бохирдлын эх үүсвэр, төв цэг рүҮ ойртох тусам шилмэл болон хэвийн моддын эзлэх тоо багасаж, доогуур чанарын моддын 
эзлэх хувь нэмэгдж байгааг харуулж ургацын байдлыг А.А. Корчагины байна.

“Үрлэлтийн зэргийг тодорхойлох арга"-

Моддын үрлэлтийн үнэлгээ

Сонгогдсон талбайн моддын үрийн үзүүлэв.

Хүснэгт 5. Моддын үрлэлтийн үнэлгээ

\begin{tabular}{|c|c|c|c|c|}
\hline \multirow{2}{*}{$\begin{array}{c}\text { Дээж } \\
\text { талбай }\end{array}$} & \multirow{2}{*}{$\begin{array}{c}\text { Хотоос алслагдах } \\
\text { зай }\end{array}$} & \multicolumn{3}{|c|}{ Корчагины үрлэлтийн үнэлгээ } \\
\hline & & $2014 \mathrm{OH}$ & 2015 он & $2016 \mathrm{oH}$ \\
\hline \multicolumn{5}{|c|}{ Хотоос хойд зүгт байрлах цэгүүд } \\
\hline Ш & 10 км & 1/ маш бага & 2/ бага & 0/үрлээгүй \\
\hline Я & 15 км & 1/ маш бага & 2/ бага & 1/ маш бага \\
\hline Ж & 20 км & 1/ маш бага & 3/ дунд & 2/ бага \\
\hline ОБ & 30 км & 2/ бага & 3/ дунд & 2/ бага \\
\hline \multicolumn{5}{|c|}{ Хотоос урд болон зүүн урд зүгт байрлах цэгүүд } \\
\hline 3 & 10 км & 1/ маш бага & 2/ бага & 0/үрлээгүй \\
\hline $\mathrm{XT}$ & 15 км & 2/ бага & $4 /$ их & 3/ дунд \\
\hline Ч & 20 км & 1/ маш бага & 3/ дунд & 1/ маш бага \\
\hline ШХ & 30 км & 2/ бага & 5/ маш их & 3/ дунд \\
\hline
\end{tabular}

Үрийн ургацыг тодорхойлоход 2014 онд үрлэлт бага дунджаар 1-2 баллын үнэлгээтэй буюу наран талдаа титмийн орой болон дунд хэсэгт цөөн тооны боргоцойтой, 2015 онд үрлэлтийн байдал харьцангуй сайн буюу дунджаар 3-4 баллын үнэлгээтэй, титмийн дунд, оройн хэсэгт, ихэнх мөчир дээр олон боргоцойтой, 2016 онд үрлэлтийн байдал нилээн ялгаатай Залаатын ам, Шадивлангийн амны ойд үрлээгүй, Яргайтын ам, Чулуутын аманд маш бага үрлэсэн, бусад талбайнуудад дунджаар 2-3 баллын үнэлгээтэй байв.

Судалгаа гүйцэтгэсэн 2014-2016 онуудын үрлэлтийн явцыг нэг хүчин зүйлт вариансын анализаар илэрхийлэхэд үрлэлт нь статистикийн хувьд $(\mathrm{p}=0.001)$ ялгаатай байна. Yp боловсрох явцад тухайн жилүүдийн уур амьсгалын нөхцөл тухайлбал, ургамал ургалтын үеийн чийг, агаарын температур, хур тунадас, агаарын харьцангуй чийг зэрэг үзүүлэлтүүдээс хамаарч үрлэлтийн байдал ялгаатай байна. Yp, боргоцойн морфологи ҮзҮүлэлтүуд, үрийн чанар Судалгааны талбайгаас бэлтгэсэн $\mathrm{pp}$, боргоцойн биометр хэмжээсүүдийн үзүүлэлтийг тодорхойлон дараах хүснэгтээр үзүүлэв.

ХУснэгт 6. Боргоцчойн биометр хэмжээс

\begin{tabular}{|c|c|c|c|c|c|c|}
\hline \multirow{2}{*}{$\begin{array}{c}\text { Дээж } \\
\text { талбай }\end{array}$} & \multicolumn{6}{|c|}{ Урт, мм } \\
\cline { 2 - 7 } & Дундаж & $\begin{array}{c}\text { Хамгийн их } \\
\text { утга }\end{array}$ & $\begin{array}{c}\text { Хамгийн бага } \\
\text { утга }\end{array}$ & Дундаж & $\begin{array}{c}\text { Хамгийн их } \\
\text { утга }\end{array}$ & $\begin{array}{c}\text { Хамгийн бага } \\
\text { утга }\end{array}$ \\
\hline \multicolumn{7}{|c|}{ Хотын хойд зүгт байрлах цэгүүд } \\
\hline Ш & $35.3 \pm 4.5$ & 44.9 & 26.0 & $24 \pm 2.5$ & 28.7 & 17.9 \\
\hline Я & $29.4 \pm 4.6$ & 41.6 & 23.3 & $21.6 \pm 2.8$ & 28.7 & 17.3 \\
\hline Ж & $34.3 \pm 5.6$ & 48.9 & 22.3 & $20.8 \pm 2.8$ & 26.1 & 14.0 \\
\hline
\end{tabular}




\begin{tabular}{|c|c|c|c|c|c|c|}
\hline ОБ & $30.2 \pm 3.9$ & 40.0 & 22.6 & $20.6 \pm 1.9$ & 24.4 & 15.9 \\
\hline \multicolumn{7}{|c|}{ Хотын урд зүгт байрлах цэгүүд } \\
\hline 3 & $32.5 \pm 4.6$ & 41.9 & 25.5 & $22.7 \pm 3.2$ & 29.5 & 17.5 \\
\hline ХТ & $32.9 \pm 3.3$ & 39.0 & 26.2 & $21.8 \pm 2.2$ & 27.9 & 16.5 \\
\hline Ч & $30.0 \pm 2.5$ & 35.2 & 24.2 & $21.5 \pm 2.0$ & 26.6 & 17.7 \\
\hline ШХ & $30.4 \pm 4.3$ & 36.8 & 16.8 & $22.2 \pm 4.6$ & 32.4 & 11.1 \\
\hline \multicolumn{7}{|c|}{} \\
\hline УБ & $29.2 \pm 8.9$ & 41.2 & 13.1 & $17.5 \pm 6.7$ & 27.1 & 7.5 \\
\hline
\end{tabular}

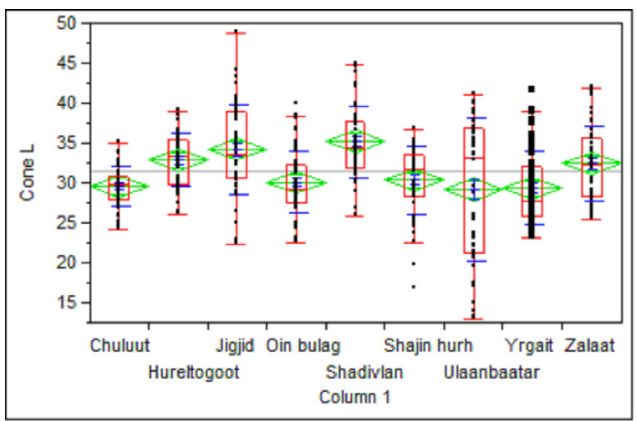

Зураг 6. Боргоцойн уртын ялгаа $F=10.3745 d f=8 p=0.0001$

Нэг хүчин зүйлт вариансын анализийн шинжилгээгээр судалгааны талбайгаaс бэлтгэсэн боргоцойн биометр хэмжээсүүдийн үзүүлэлтүүд нь статистикийн хувьд ялгаатай $(p=0.0001)$ байгаа бөгөөд дээж талбай тус бүрийн боргоцойн биометр хэмжээсүүдийг

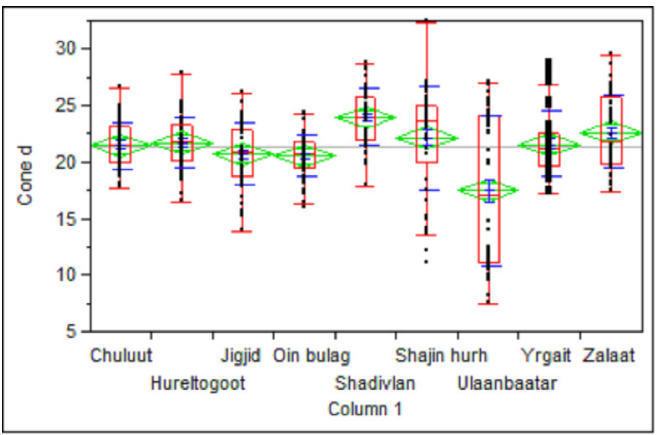

Зураг 7. Боргоцчойн өргөний ялгаа $F=12.8123 d f=8 p=0.0001$

T тестээр ангилж үзэхэд Жигжид, Шадивлангаaс бэлтгэсэн боргоцойн үзүүлэлт хамгийн сайн буюу $\mathrm{A}$, хамгийн бага үзүүлэлттэй нь Улаанбаатар хотын ногоон байгууламжаас бэлтгэсэн боргоцойн С үнэлгээтэй байна.

ХУснэгт 7. Үрийн биометр хэмжээс

\begin{tabular}{|c|c|c|c|c|c|c|}
\hline \multirow{2}{*}{$\begin{array}{c}\text { Дээж } \\
\text { талбай }\end{array}$} & \multicolumn{7}{|c|}{ Урт, мм } & \multicolumn{3}{c|}{ Өргөн, мм } \\
\cline { 2 - 7 } & Дундаж & $\begin{array}{c}\text { Хамгийн их } \\
\text { утга }\end{array}$ & $\begin{array}{c}\text { Хамгийн бага } \\
\text { утга }\end{array}$ & Дундаж & $\begin{array}{c}\text { Хамгийн их } \\
\text { утга }\end{array}$ & $\begin{array}{c}\text { Хамгийн бага } \\
\text { утга }\end{array}$ \\
\hline \multicolumn{7}{|c|}{ Хотын хойд зүгт байрлах цэгүүд } \\
\hline Ш & $4.6 \pm 0.4$ & 5.4 & 3.7 & $3.0 \pm 0.2$ & 3.4 & 2.4 \\
\hline Я & $4.9 \pm 0.5$ & 5.9 & 4.1 & $3.2 \pm 0.4$ & 4.8 & 2.6 \\
\hline Ж & $4.7 \pm 0.4$ & 5.4 & 3.8 & $3.0 \pm 0.2$ & 3.6 & 2.6 \\
\hline ОБ & $3.8 \pm 0.5$ & 4.7 & 2.6 & $2.8 \pm 0.4$ & 3.9 & 1.9 \\
\hline \multicolumn{7}{|c|}{ Хотын урд 3үгт байрлах цэгүүд } \\
\hline 3
\end{tabular}




\begin{tabular}{|c|c|c|c|c|c|c|}
\hline ХТ & $4.0 \pm 0.7$ & 5.2 & 2.1 & $2.7 \pm 0.7$ & 4.0 & 1.2 \\
\hline Ч & $4.5 \pm 0.4$ & 5.6 & 3.8 & $3.1 \pm 0.2$ & 3.9 & 2.5 \\
\hline ШХ & $4.8 \pm 0.4$ & 5.6 & 3.7 & $3.0 \pm 0.3$ & 3.8 & 2.4 \\
\hline \multicolumn{6}{|l|}{ Хяналт } \\
\hline УБ & $5.0 \pm 0.4$ & 5.9 & 4.3 & $3.1 \pm 0.3$ & 3.9 & 2.6 \\
\hline
\end{tabular}

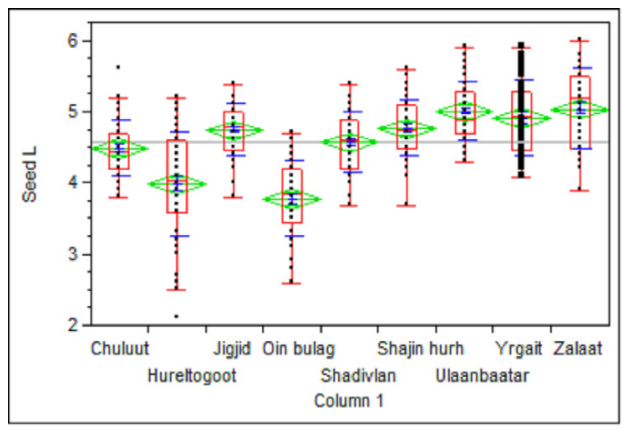

Зураг 8. Үрийн уртын ялгаа $F=40.1709 d f=8 p=0.0001$

Үрийн биометр хэмжээсийн үзүүлэлтэнд хийсэн нэг хүчин зүйлт вариансын анализийн шинжилгээгээр судалгааны талбайгаас бэлтгэсэн үрийн урт болон өргөний үзүүлэлтүүд нь статистикийн хувьд ялгаатай $(\mathrm{p}=0.0001)$ байгаа бөгөөд дээж талбай тус бүрийн үрийн биометр хэмжээсүүдийг $\mathrm{T}$ тестээр ангилж үзэхэд Улаанбаатар, залаатын амнаас бэлтгэсэн үрийн үзүүлэлт хамгийн сайн буюу $\mathrm{A}$, хамгийн бага үзүүлэлттэй нь ойн булагаас

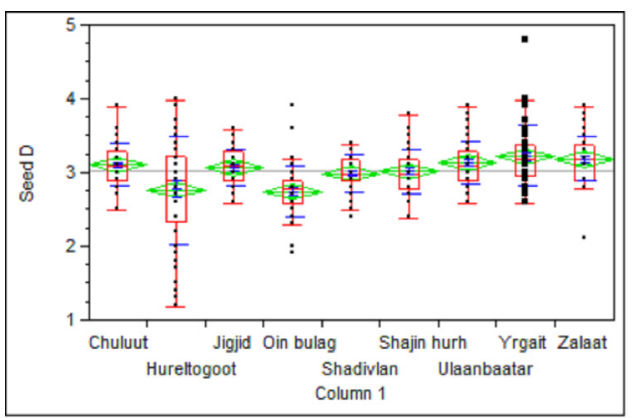

Зураг 9. Үрийн өргөний ялгаа $F=9.9506 d f=8 p=0.0001$

бэлтгэсэн үрний үзүүлэлт С үнэлгээтэй байна.

Үрийн дээж цуглуулсан талбай тус бүрийн үрийн чанарын үзүүлэлтүүдийн ялгааг нэг хүчин зүйлт вариансын анализаap (One-Way ANOVA) илэрхийлэхэд соёололт, ургах эрчим, 1000 үрийн жингийн үзүүлэлтээрээ дээж талбай тус бүрийн үрийн чанарын үзүүлэлтүүд нь статистикийн хувьд $(p=0.001)$ ялгаатай байна.

Хүснэгт 8. Үрийн чанарын ҮзҮҮлэлт

\begin{tabular}{|c|c|c|c|c|c|c|c|}
\hline \multirow{3}{*}{$\begin{array}{c}\text { Дээж } \\
\text { талбай }\end{array}$} & \multirow{3}{*}{$\begin{array}{c}\text { Хотоос } \\
\text { алслагдах } \\
\text { зай }\end{array}$} & \multicolumn{6}{|c|}{ Үрийн чанар } \\
\hline & & \multicolumn{2}{|c|}{ Ургах эрчим, \% } & \multicolumn{2}{|c|}{ Соёололт, \% } & \multicolumn{2}{|c|}{1000 үрийн жин, г } \\
\hline & & 2015 & 2016 & 2015 & 2016 & 2015 & 2016 \\
\hline \multicolumn{8}{|c|}{ Хотын хойд зүгт байрлах цэгүүд } \\
\hline Ш & 10 км & 42.3 & - & 75.3 & - & 6.7 & - \\
\hline Я & 15 км & 45.7 & 43.6 & 72.7 & 76 & 6.5 & 6.8 \\
\hline Ж & 20 км & 49.3 & 27.8 & 84.0 & 46 & 6.6 & 7.1 \\
\hline ОБ & 30 км & 26.7 & 45.2 & 74.0 & 82 & 7.3 & 7.6 \\
\hline \multicolumn{8}{|c|}{ Хотын урд зүгт байрлах цэгүүд } \\
\hline 3 & 10 км & 27.3 & - & 67.7 & - & 6.9 & - \\
\hline XT & 15 км & 71.0 & 52.8 & 84.7 & 82 & 7.7 & 8.5 \\
\hline
\end{tabular}




\begin{tabular}{|c|c|c|c|c|c|c|r|}
\hline Ч & 20 км & 31.0 & 46.7 & 65.0 & 74 & 6.7 & 7.1 \\
\hline ШХ & 30 км & 52.0 & 46.6 & 85.0 & 76 & 6.7 & 7.3 \\
\hline \multicolumn{7}{|c|}{ Хяналт } \\
\hline $\begin{array}{c}\text { Уб хот } \\
\text { нб }\end{array}$ & - & 26.3 & - & 40.3 & - & 6.4 & \\
\hline
\end{tabular}

Үрийн жин нь моддын удамшлын шинж чанар болон үрийн ургалтын чанарыг тодорхойлох чухал шинж тэмдгүүдийн нэг бөгөөд тарьц ургах эхний үеүдэд чухал нөлөө үзүүлэхээс гадна орчны тааламжгүй нөхцөлийг тэсвэрлэх чадварыг илтгэх Үзүүлэлт болдог байна [10]. Ургах орчны тохиромжгүй нөхцөлд 1000 үрийн жингийн хэлбэлзэл нилээд илрэх ба модны титэм дэх боргоцойн байрлал, модны нас, ойн титэм нийлэлт ба цаг уурын онцлогоос хамаарч хэлбэлздэг. ЭнэхүҮ үзүүлэлт нь удамшлын чухал шинж, өөрөөр хэлбэл гадаад орчны нөхцөлийн хэлбэлзэлд хэдийчинээ бага өртөж, тэсвэрлэж гарах чадварыг илтгэх үзүүлэлт болох бөгөөд хотын ногоон байгууламжаас бэлтгэсэн үр 6.4 г буюу бусад талбайн үзүүлэлттэй харьцуулахад хамгийн бага байна.

Үрийн соёололтын хувиас үзэхэд (2015) Улаанбаатар хотоос өмнө зүгт 10 км зайд сонгосон талбайнх $67.7 \%, 15$ км зайд сонгосон талбайнх 84.7\%, 20 км зайд сонгосон талбайнх 65\%, 30 км зайд сонгосон талбайнх $85 \%$, хойд зүгт сонгосон талбайн хувьд 10 км зайд сонгосон талбайд $75.3 \%, 15$ км зайд сонгосон талбайд 72.7\%, 20 км зайд сонгосон талбайд 84\%, 30 км зайд сонгосон талбайд 74\%, хотын ногоон байгууламжинд ургаж буй шинэсний үрэнд

\section{ДУГНЭЛТ}

Үрийн ургацын үнэлгээгээр хотын ногоон бүсийн шинэсэн ойд 2014 онд 1-2 балл, 2015 онд 3-4 балл, 2016 онд 2-3 балл байгаа бөгөөд үрлэлтэнд тухайн жилийн уур амьсгалын нөхцөл нөлөөлж, үрлэлтийн байдал судалгааны талбай тус бүрт ялгаатай байгааг харуулна.
40.3\% тус тус байна. 2016 онд судалгааны дээж талбайнуудаас бэлтгэсэн үрийн чанарын үзүүлэлтэнд энэхүҮ зүй тогтол мөн адил давтагдана.

Үрийн соёололтын хувиас Үзэхэд (2016) Улаанбаатар хотоос өмне зүгт 15 км зайд сонгосон талбайнх 82\%, 20 км зайд сонгосон талбайнх 74\%, 30 км зайд сонгосон талбайнх 76\%, хойд зүгт сонгосон талбайн хувьд 15 км зайд сонгосон талбайд 76\%, 20 км зайд сонгосон талбайд 46\%, 30 км зайд сонгосон талбайд $82 \%$ байна. Эндээс үзэхэд агаарын бохирдол ихтэй төв цэгтэй ойр талбайгаас бэлтгэсэн үрийн үрлэлт болон чанарын үзүүлэлтэнд ургах орчны нөхцөл, агаар бохирдуулагч эх үүсвэрүүдийн нөлөө байгааг харуулж байна.

Судалгааны дүнгээс үзэхэд сибирь гацуурын үрийн соёололт болон амьдрах чадварын үзүүлэлт буурахад агаар дахь хүхрийн давхар исэл болон хүнд металлууд сөрөг нөлөө үзүүлсэн болохыг судалжээ [12]. Мөн агаарын бохирдол ихтэй хотын төв цэгээс алслагдах байдлаар ялгаатай газраас бэлтгэсэн нарсны үрийн соёололт, ургах эрчим, 1000 үрийн жин, үр, боргоцойн хэмжээ зэрэг үзүүлэлтүүдэд мэдэгдэхүйц ялгаа илэрсэн $[13,14]$ нь бидний судалгааны үр дүнг батлан харуулж байна.

Агаарын бохирдол нь үрийн чанарын үзүүлэлтүүдэд сөрөг нөлөө үзүүлж, бохирдол ихтэй хот орчмын талбайнуудад хамгийн бага үзүүлэлттэй тухайлбал, хотын ногоон байгууламжаас бэлтгэсэн үрний 1000 үрийн жин 6.4 г, ургах эрчим 26.3\%, соёололт $40.3 \%$ буюу хамгийн доогуур 
Үзүүлэлттэй байгааг тогтоов.

Моддын өсөлтийн ангиллаас үзэхэд агаарын бохирдол харьцангуй багатай хотын урд зүгт сонгосон талбайн моддын $57.7 \%$ нь I-III ангилалд, 42.3\% нь IY-Y ангилалд, хойд зүгт сонгосон талбайнуудад $52.5 \%$ нь I-III ангилалд, $47.5 \%$ нь IY-Y тус тус хамаарагдах бөгөөд моддын өсөлтөнд агаарын бохирдол болон ойн рекраци ашиглалт сөрөг нөлөө үзүүлнэ.

Селекцийн ангиллаар $8.5 \%$ нь шилмэл буюу өсөлт хөгжилт сайтай, иш шулуун, жигд бүдүүрэлтэй, хажуугийн мөчрөөс чөлөөлөгдсөн, титмийн хөгжил жигд модод, $45.8 \%$ хэвийн, $45.7 \%$ нь доогуур чанарын өсөлт хөгжилт муутай, харьцангуй нарийн, салаалсан, соготой, өвчин хортон болон механик гэмтэлтэй модод тархаж байна.

\section{НОМ ЗYЙ}

1. Анучин Н.П. 2004. Лесная таксачия. Учеб. Для вузов. 6-е изд. -М. ВНИИЛМ, 552 с

2. Белов С.В. 1953. Лесоводство. М., “Лесная промышленность" 349 с.

3. Гиргидов Д.Я. 1968. Научные основы и практика создания лесосеменных участков и плантаций сосны в северо-западных областях РСФСР: Дисс...канд. с. - х. Наук.Ленинград:, с. 201-211

4. Гиргидов Д.Я. 1976. Семеноводмтво сосны на селекиионной основе.- М.: Лесн. пром-сть, - $64 \mathrm{c}$

5. Корчагин А.А. 1960. Методы учета семенономения древесных пород и лесных сообществ.-М.: -T.II. с41-132

6. Любавская А.Я. 1982. Лесная селекиия и генетика.-М: Лесная пром-сть, с 206

7. “Нийслэлийн ногоон бүсийн ойн сан” ой зохион байгуулалтын ажлын тайлан. УБ, 2008

8. Ойн ажлын стандарт. 2012. //гарын авлага. УБ, х 37-102.

9. Тараканов В.В., Демиденко В.П., Ииутин Я.Н., Бушков Н.Т. 2001. Селекиионное семеноводство сосны обыкновенной в Сибири.-Новосибирск: Наука,-230 с.

10. Udval B, Batkhuu N.-O., 2013. Seed and Cone Characteristics of Scots pine (Pinus sylvestris L.) from Diverse Seed Sources in Northern Mongolia. Eurasian J. For. Res 16:1, pp. 51-56

11. Chonopouls J., Haidouti C., et all. 1997. Variations in plant and soil lead and cadmium content in urban parks in Athens, Greece. Sci. Total Environ. 196, 91-98

12. Grubb P.G., Coomes D.A. 1997. Seed mass and nutrient content in nutrient starved tropical rainforest in Venezuela. Seed Science Res, 7: 269-280.

13. Onder S., Dursun S. 2006. Air borne heavy metal pollution on CedrusIibani (A rich.) in the city centre of Konya (Turkey). Atmos. Environ.40, 1122-1133

14. Petros G., Marianthi T., Georgios Z. 2011. Effect of air traffic pollution on seed quality characteristics of Pinus brutia. Environmental and Experimental Botany 74, 157-161

15. International Seed Testing Association (ISTA). 1999. International rules for seed testing. Seed Science and technology, 21 (Suppl.) 


\title{
THE EFFECT OF AIR POLLUTION ON SEED YIELD AND QUALITY IN THE GREEN ZONE FOREST
}

\author{
B. Udval ${ }^{1}$, Ts.Dashzeveg ${ }^{1}$ \\ Institute of Geography and Geoecology, Mongolian Academy of Sciences \\ E-mail: bayarsaikhanudval@gmail.com
}

The study sites are located in green zones in Ulaanbaatar. Ulaanbaatar is situated in the central part of the country, in the Tuul river valley, at an average height of $1350 \mathrm{~m}$ above sea level. In recent year's air pollution of Ulaanbaatar city has become the main problem of increasing population and coal burning in informal residential areas, industrial boiler, power plants, motor vehicles, household heating systems. We have established 8 sample plots, which are situated in western and east part of the city and separated from each other by $10,15,20,30 \mathrm{~km}$. We have evaluated all trees in the research plots according to Korchagin's seed crop evaluation and results show that 2014 year has lower seed crops (1 category by Kraft's classification) than that 2015 year (4 category by Kraft's classification). The seed quality was examined by weight of 1000 seeds, germination energy, and germination capacity on every sample plots. The study results showed significant differences in seed quality among sample plots.

We have evaluated all trees in the established plots according to (I) Kraft's classification on tree growth performance and (II) scale categories properties of trees. As a result of the evaluation, research sites in Shadivlan, Yargait, Khurel Togoot, Zalaat has a common issue. That was reduced growth of trees due to improper human influence and air pollution. Finally, air pollution and recreation use in green zones of the city has direct impact on tree growth and general attribution of the forests.

Keywords: seed yield, germination, germination capacity, weight of 1000 seed, seed, cone, seed wing; 